\title{
Optimization of the sown areas structure as a tool for the development of medicinal crop production on the basis of sustainability and regenerative agriculture
}

\author{
Tetiana Mirzoieva ${ }^{1, *}$, Violeta Heraimovych $^{1}$, Yuliia Loshakova $^{1}$, Marian Tripak $^{2}$, and Iryna \\ Humeniuk $^{2}$
}

${ }^{1}$ National University of Life and Environmental Sciences of Ukraine, Ukraine

${ }^{2}$ Podilsky Special Education and Rehabilitation Socio-Economic College, Ukraine

\begin{abstract}
On the compliance with current requirements for the search for new alternative intensive models of agricultural production, the article has analyzed the structure of sown areas of farms in the Ukrainian Veld zone with an area of agricultural land up to 50 hectares; factors that indicate the need to optimize the structure of crops to meet the requirements of sustainable development and regenerative agriculture has been identified; the role of crop rotations in the system of modern agriculture has been revealed; the assumption that the tool of optimization of sown areas can be inclusion of medicinal plants in them has been put forward and substantiated; an optimization model has been built, with the help of which, based on production resources (land, labor, material, etc.), the optimal structure of sown areas of farms in the Ukrainian Steppe zone with an area of agricultural land up to 50 hectares has been determined; on the basis of the optimization economic-mathematical model with the help of the simplex method the increase of profitability of agricultural production has been calculated; the optimal structure of sown areas of the studied farms of the Ukrainian Veld zone with the introduction of medicinal plants has been developed.
\end{abstract}

\section{Introduction}

In recent decades, the concept of sustainable development has become widespread, which does not lose its relevance today. In its field of vision is a wide range of issues, including - ensuring the transition to models of balanced consumption and production; balanced management of natural resources; conservation, restoration and balanced use of terrestrial ecosystems, restoration of degraded lands and soils with the use of innovative technologies. The search and implementation of new alternative intensive models of agricultural production is becoming increasingly important in the framework of sustainable development. Moreover, all such modern models are based on the concept of obtaining a

\footnotetext{
* Corresponding author: mirzoeva2018@ukr.net
} 
high-quality harvest without harming the environment. In particular, today the alternative methods of agricultural production, scientists and practitioners include: organic farming; biointensive mini-farming; biodynamic-agriculture; low input sustainable agriculture LISA; precision farming; regenerative agriculture (Kaminsky V., 2014, Kuzio N., 2020, Galushkina T., 2000). These models provide a deep understanding of the processes occurring in nature, aimed at improving soil structure and reproduction of their natural fertility and, ultimately, contribute formation of ecologically sustainable agro-landscapes. In today's conditions, these alternative areas of agricultural production are becoming increasingly popular. And regenerative agriculture is even attributed to the agrarian trends of the new decade, along with efficient water use, technical side of production processes and niche diversification (Kuzio N., 2020). and considered as a comprehensive approach to the cultivation of crops, vegetables and fruits without the use of pesticides, chemical fertilizers. The purpose of such activities is to stimulate natural soil regeneration, use fresh water efficiently, increase biodiversity, adapt to climate change and improve the well-being of those who work on the land (Gastronomic Trends 2020, 2020).

Such direction of the agricultural sector as the production of medicinal plants, which is developing rapidly in the modern world inextricably linked with the goals of sustainable development and regenerative agriculture. For example, Iranian scientists Jafari H., Ahmadian M. A., \& Tarhani A. (2017) present the concept of rural areas development on the basis of sustainable development. The concept is based on the fact that at this stage of development on the one hand there is a need to increase the utilization of production capacity, and on the other hand economic activity in rural areas should be diversified. The development of medicinal plant production can be an approach to economic stabilization in rural areas within the model of their sustainable development. However, Lange, D. (2004) notes that medicinal and aromatic plants are well suited to the objectives of the Convention on Biological Diversity.

We believe that the concept of sustainable development is based on three defining imperatives: environmental, which determines the conditions and limits of restoration of ecological systems as a result of their operation; economic, which involves the formation of an economic system consistent with the environmental factor of development; social, which affirms the human right to work and well-being in terms of environmental safety, can be the basis for the strategic development of the field of medicinal plants (Strategic Priorities..., 2018). In particular, during building a methodological platform for the strategy of development of medicinal crop production, it is worth paying attention to such an effective tool of regenerative agriculture as the spread of crop rotation and the introduction into the structure of crops of medicinal plants. Today,, science and practice have shown that long and varied crop rotations are the key to successful control of insects and weeds, plant diseases, to preventing soil erosion, promotion of the organic problems formation and soil fixation, increasing of biodiversity, and generally improving of the soil quality. In addition, crop rotation system can prevent threatening of the crop yields reducing. Thus, the system of crop rotations with a corresponding reduction in material costs for $50-70 \%$ affects the yield, while other factors: various tillage technologies, controls of weeds and diseases, fertilizer use and organization of the seed system affect only 10, 20, 30 and $40 \%$ respectively (Kvasnitska LS, 2019).

Therefore, it can be argued that crop rotation for the agricultural producer is one of the tools of efficient activity and, at the same time, a tool of sustainable use of land resources. Given the above, the purpose of this study is to attempt to optimize the structure of sown areas with the inclusion of a set of major crops - medicinal crops in accordance with the requirements of sustainable development, regenerative agriculture and niche diversification.

\section{Methodology}


Within the framework of this study, the increase in the agricultural production profitability was calculated on the basis of the optimization economic-mathematical model using the simplex method. The objective function of the model is to obtain the maximum profit from sales.

\section{Results and Discussion}

First of all, it should be noted that one of the functions of medicinal plant growing is ecological. Its essence is that the conservation and enrichment of biodiversity in nature is possible through the cultivation of medicinal plants and the care of wild medicinal crops by maintaining their biodiversity, productivity, ability to recover and without damaging other ecosystems. First of all, taking to attention the function of medicinal plant growing, the zone of the Ukrainian Veld has been chosen for modeling. The choice is this zone due to the next facts:

1. This zone like no other in Ukraine, in today's conditions is experiencing the effects of climate change, the effects of exhausting intensive agriculture, the effects of existing disparities in the structure of crops. For example, climate change (drought, frost, dust storms) in recent years has caused large crop losses in this area. Due to global warming, it is becoming increasingly difficult to grow traditional crops - sunflower, corn, wheat, etc. Secondly, in Ukraine due to intensive agricultural production in the last twenty years, as well as around the world, the condition of soils has deteriorated significantly. As a result, the yield of traditional crops is declining. World grain prices also tend to decline. For Ukraine, which is one of the leaders in grain production on the world stage, these facts are extremely negative. Therefore, Ukrainian farmers are increasingly considering the possibility of diversifying production and entering new market niches, which are exportoriented. Accordingly, for farmers of the Ukrainian Veld there is an urgent need to reorient production to drought-resistant crops and crops that have the ability to improve soil quality (Mirzoieva T., 2019, Mirzoieva T., Tomashevska O., 2020) [1-6].

As it has been found in the process of the study such requirements meet a number of medicinal crops;

2. the production of medicinal plants in Ukraine is concentrated mainly in large specialized enterprises, so the market is very monopolized. At the same time, according to world experience, it is expedient to develop medicinal plant growing in farms, the vast majority of domestic farms in Ukraine, in particular 55\%, are in the veld zone - 15252 farms, and they were selected as the object of study in building an optimization model. These farms in 2020 cultivated 2806 thousand hectares of agricultural land;

3. currently 896 species of medicinal plants have been found in the veld zone of Ukraine, but the resource potential of the majority is not fully used due to the high level of economic development of the territory where industrial cultivation is carried out mainly of a sunflower and wheat. At the same time, there are 23 raw material species in the set of medicinal plants of the veld zone - these are, for example, resources of thyme, chamomile, St. John's wort and other important for human plants (Minarchenko V., 2016).

The object of the study is small farms in the Ukrainian veld zone, which are up to 50 hectares of agricultural land, given that, the largest section of farms in the veld zone is farms with an area of $20-50$ hectares $(36,7 \%)$. In their land use is $7,7 \%$ of agricultural land (Fig. 1). The total number of such farms in this area as of 2019 was 8,688 units with an area of up to 50 hectares and with land use of 249,1 thousand hectares of agricultural land. In addition, the choice of enterprises for this study was influenced by the fact that the production of medicinal plants in Ukraine mainly specialize in small enterprises with sown areas up to 10 hectares. By the way, the yield of medicinal plants in the groups of the studied enterprises is the highest in mini-farms with a sown area of up to 10 hectares. 


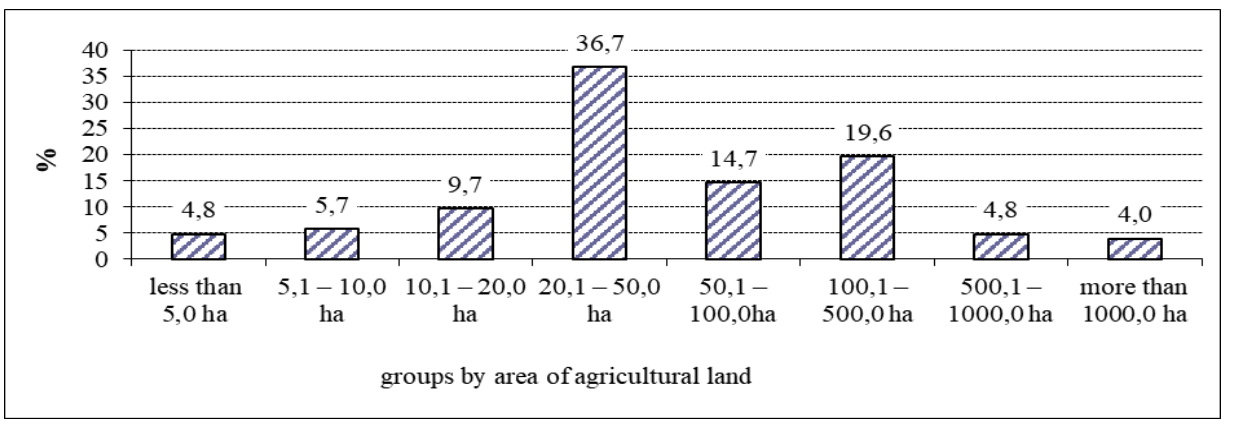

Fig. 1. Part in amount of different sizes farms in veld areas in 2019,\%. Source: Developed by the authors using the data from the State Statistics Service of Ukraine.

Medicinal plant growing in Ukraine is in its infancy and is uncommon among farmers, despite its importance around the world. Realizing that even under the condition of clearly directed development of medicinal plant growing with the support of the state, not all farmers, for one reason or another, diversify production activities by cultivating medicinal crops, this study suggested that a third part of farmers can grow medicinal plants in the Ukrainian veld farms. Given that the production of medicinal plants is the extremely risky business, the assumption that exactly one-third of farmers in the veld will be able to engage in medicinal plant production is based on the existing risk division of all business entities into groups in relation to risk: 1-st group - not exposed to risk; 2nd group - risk neutral; 3rd group - prone to risk, those ones who prefer a risky result relative to the guaranteed (Gerasimchuk NA, 2020).

Accordingly, we assume that: a third part of farmers are not at risk and do not want to disrupt business which has been stable and well-established for many years; another third part will take some time to weigh all the pros and cons; and a last third part of farmers, who are characterized by a risk appetite and the introduction of a new one, will immediately assess the economic benefits of cultivating medicinal plants, introducing them into the structure of crops and will find the opportunity to accumulate funds to start a new line of activity. In a separate third of farms in the veld zone, the area of agricultural land is 62,3 thousand hectares, and sown $-55,74$ thousand hectares. The identified farms are given as the object of this study to model the structure of crop rotations.

First of all, it should be noted that after analyzing the structure of sown areas of farms up to 50 hectares of agricultural land in the Ukrainian veld zone it was found that isolated farms do not follow scientifically sound crop rotations and do not grow many important food security crops. Thus, the largest section in crops in 2019 was occupied by cereals $58,4 \%$, and the section of sunflower seeds in crops was $36,0 \%$. The section of winter wheat $(29,5 \%)$ in the structure of sown areas in 2019 in isolated farms of the veld zone with an area of agricultural land up to 50 hectares was quite significant, and niche crops accounted for only $2 \%$. The most common legume in the region is peas - one of the best precursors for winter crops (table 1). Industrial crops grown in the region are relatively profitable, so Ukrainian farmers often sow them on unreasonably large areas, especially sunflower. In this case, the sunflower is usually grown without taking into account its biological characteristics and its impact on the yield of subsequent crops, as well as with significant violations of cultivation technology. As a result, the excessive section of this crop in the structure of sown areas (over 15\%) causes drying of both surfaces and deep soil layers, which, in return, negatively affects the yield for the next 2-3 crops. The placement of a sunflower in crop rotation after unsightly predecessor crops and growing this crop in repeated and permanent crops is quite common, which also causes significant depletion and drying of soils (on approval, 2010, Sobko Z., Voznyuk N., 2017 ). 
So, due to the fact that Ukrainian farmers are largely dependent on the results of commercial activities and in their activities focus primarily on growing profitable crops, their range has catastrophically narrowed. The southern part of the Ukrainian veld zone has the greatest tendency to narrow the range of crops grown.

Table 1. The structure of sown areas of farms up to 50 hectares of agricultural land in the steppe zone of Ukraine, 2019

\begin{tabular}{|c|l|l|}
\hline Grain culture & Area, ha & $\%$ \\
\hline All grains & 32536.6 & 58.4 \\
\hline Winter wheat & 16464.6 & 29.5 \\
\hline spring wheat & 223.2 & 0.4 \\
\hline Winter grain & 82.1 & 0.1 \\
\hline buckwheat & 47.9 & 0.1 \\
\hline Corn & 4820.2 & 8.6 \\
\hline Winter barley & 5342.7 & 9.6 \\
\hline Spring barley & 4570.2 & 8.2 \\
\hline Pea & 357.8 & 0.6 \\
\hline Oats & 158.5 & 0.3 \\
\hline Millet & 392.9 & 0.7 \\
\hline Sotghum & 76.5 & 0.1 \\
\hline sunflower & 20061.4 & 36.0 \\
\hline Soy & 2285.8 & 4.1 \\
\hline Turnip & 856.2 & 1.5 \\
\hline Source: Deving & & \\
\hline
\end{tabular}

Source: Developed by the authors using the data from the State Statistics Service of Ukraine.

In general, as it is revealed in the study, since the $90 \mathrm{~s}$, both in all the territory of Ukraine and in the Ukrainian veld zone in particular, there has been a catastrophically dangerous expansion of sown areas occupied by a sunflower and a total uncontrolled reduction of sown areas of other crops, and what for the medicinal crops, in general they received very little attention from Ukrainian farmers.

It should be noted that there are many effective tools in the world to mitigate the negative trends caused by climate change and debilitating agriculture. For example, people of China are implementing a grand project which aimed to stop the desert's attack on fertile arable land. In Turkmenistan, the population is successfully resisting the expansion of the Kara-Kum Desert by expanding the green area. In Ukraine, the existing market system for growing crops is still waiting for constructive changes.

As a result of the analysis of the structure of sown areas of farms of the Ukrainian veld zone with the area of agricultural lands up to 50 hectares, it was concluded that it is an urgent need is to optimize the structure of sown areas, which will: - increase crop yields; increase the profit (income) of enterprises; - diversify production; - increase the level of employment of the rural population, especially in the case of introduction into the structure of crops of medicinal plants; - improve the quality of soils (Optimization of sown areas G., 2013, Boyko PI, 2018).

At the first stage, an optimization model, which, based on production resources (land, labor, material, etc.), determined the optimal structure of sown areas of farms in the steppe zone with an area of agricultural land up to 50 hectares was built, which potentially can provide agronomic and crop rotation requirements with the maximum economic effect. In resolving this issue, the author was guided by the methodological recommendations developed by the Ukrainian government on the optimal ratio of crops in crop rotations of different soil and climatic zones of Ukraine (on approval of standards G., 2010), according 
to whom the criterion of optimality can be: - maximum profit from production; - the maximum volume of production of gross and commodity production in monetary terms; the maximum volume of production of specific products (grain, milk, etc.) [7-13].

Within the framework of this study, the increase of the profitability of agricultural production was calculated on the basis of the optimization economic-mathematical model using the simplex method. The objective function of the model is to obtain the maximum profit from sales. Accordingly, due to changes in the structure of sown areas of crops grown in enterprises, it has received the estimated result - profit from sales. In addition, the process of setting this task also takes into account the minimum and maximum values of sown areas, which were also determined by the Guidelines for the optimal ratio of crops in crop rotations of different soil and climatic zones of Ukraine (on approval of standards 2010).

The construction of numerical matrices of the problem and finding their solution has been performed in the Microsoft Office Excel environment using the add-on «Find a solution».

According to the analysis of the main indicators of crop production efficiency in the studied farms of the Ukrainian Steppe zone in 2019, the choice of this zone to optimize the structure of sown areas was quite reasonable and legitimate. In particular, data in table 2 indicates a significant section of sunflower in the structure of sown areas, which is an evidence of extremely degraded structure of this production; those industrial crops, including sunflower, are super-profitable.

Table 2. The main indicators of agricultural production efficiency crops in the studied farms of the Steppe zone, 2019

\begin{tabular}{|l|l|l|l|l|l|l|}
\hline Grain culture & area, ha & $\begin{array}{l}\text { crop } \\
\text { capacity, } \\
\text { Ц/ra }\end{array}$ & $\begin{array}{c}\text { Costs for } \\
\text { ha, USD }\end{array}$ & $\begin{array}{l}\text { the average } \\
\text { selling price of } \\
\text { 1 quintal, USD }\end{array}$ & $\begin{array}{l}\text { cost of 1 quintal } \\
\text { of sold products }\end{array}$ & $\begin{array}{l}\text { profit of } 1 \\
\text { ha, USD }\end{array}$ \\
\hline Winter wheat & 16464.6 & 33.5 & 474.00 & 17.03 & 13.89 & 195.42 \\
\hline Spring wheat & 223.2 & 28.7 & 423.65 & 18.12 & 15.50 & 75.24 \\
\hline Winter grain & 82.1 & 24.8 & 320.46 & 16.31 & 13.10 & 79.66 \\
\hline buckwheat & 47.9 & 16.0 & 243.77 & 22.00 & 15.39 & 104.99 \\
\hline corn & 4820.2 & 54.4 & 597.08 & 14.31 & 11.26 & 165.95 \\
\hline Witer barley & 5342.7 & 29.2 & 435.38 & 18.82 & 15.66 & 92.39 \\
\hline Spring barley & 4570.2 & 30.2 & 381.30 & 15.38 & 13.26 & 64.14 \\
\hline pea & 357.8 & 19.8 & 403.18 & 23.56 & 20.47 & 61.22 \\
\hline oats & 158.5 & 17.1 & 218.36 & 14.02 & 13.10 & 15.65 \\
\hline millet & 392.9 & 16.6 & 327.64 & 27.08 & 19.88 & 119.43 \\
\hline sorghum & 76.5 & 35.7 & 467.79 & 19.36 & 13.68 & 202.79 \\
\hline sunflower & 20061.4 & 21.9 & 520.59 & 33.34 & 25.06 & 181.51 \\
\hline soy & 2285.8 & 19.7 & 540.15 & 32.06 & 26.71 & 105.37 \\
\hline turnip & 856.2 & 21.9 & 683.45 & 41.19 & 31.73 & 207.09 \\
\hline
\end{tabular}

The first stage of economic and mathematical modeling was the optimization of areas of cereals and industrial crops in order to find the optimal structure of sown areas, at which the profit of farms will be maximum. The required sown areas were marked: X1, X2, .... X14 - sown areas of agricultural crops in the studied farms of the Ukrainian veld zone, ha. P1, $\mathrm{p} 2 \ldots . . . \mathrm{p} 14$, US dollars.

We assumed that the objective function was linear, the constraints are also all linear, and built a mathematical model of the task, which objective function is the maximum profit from crop production in the studied farms in the veld zone.

$$
\mathrm{P}=\mathrm{p}_{1} \mathrm{x}_{1}+\mathrm{p}_{2} \mathrm{x}_{2}+\mathrm{p}_{3} \mathrm{x}_{3}+\ldots+\mathrm{p}_{14} \mathrm{x}_{14} \rightarrow \max
$$


$\mathrm{V} 1, \mathrm{~V} 2, \ldots, \mathrm{V} 7$ - actual amount of resources listed in a table. 2.

What about the cost of resources per 1 hectare of crops in the studied farms of the Ukrainian veld zone, the analysis has shown that the total annual cost of resources for growing crops present in the structure of crops in the studied population was: - seeds in the amount of 3121,6 US dollars; mineral fertilizers - 4464 US dollars; fuels and lubricants 3063 US dollars; payment for works and services of third parties - 2934 US dollars; wages with deductions for social activities - 1601 US dollars depreciation of fixed assets - 1693 US dollars; other expenses - 7957 US dollars.

As part of the construction of the economic-mathematical model, a system of constraints was also developed (within which framework there may be areas, costs, etc.). In particular:

restrictions on the use of production resources:

$$
\left\{\begin{array}{l}
a_{11} x_{1}+a_{12} x_{2}+a_{13} x_{3}+\ldots+a_{1 n} x_{n} \leq R_{1} \\
a_{21} x_{1}+a_{22} x_{2}+a_{23} x_{3}+\ldots+a_{2 n} x_{n} \leq R_{2} \\
\vdots \\
a_{m 1} x_{1}+a_{m 2} x_{2}+a_{m 3} x_{3}+\ldots+a_{m n} x_{n} \leq R_{m} \\
x_{1} \geq 0, x_{2} \geq 0, \quad \ldots \quad x_{n} \geq 0 \\
j=\overline{1, n} ; i=\overline{1, m}
\end{array}\right.
$$

where aij - coefficients that show the norms of consumption of i-resource per 1 ha of sowing of the $\mathrm{j}$-th crop;

$\mathrm{Ri}$ - total volume of the resource

$\mathrm{S}$ - area of crops.

The cost of the i-th type of resource for the production of the j-th type of product can be presented in matrix form:

$$
\underline{a_{i j}}=\left(\begin{array}{cccccc}
a_{11} & a_{12} & \ldots & a_{1 j} & \ldots & a_{1 n} \\
a_{21} & a_{22} & \ldots & a_{2 j} & \ldots & a_{2 n} \\
\ldots & \ldots & \ldots & \ldots & \ldots & \ldots \\
a_{m 1} & a_{m 2} & \ldots & a_{m j} & \ldots & a_{m n}
\end{array}\right)
$$

restrictions on the use of area:

$$
\sum_{i=1}^{n} X_{i} \leq S
$$

where $X_{\mathrm{i}}$ is the area of the i-crop;

$\mathrm{S}-$ area of agricultural crops of the household;

The area under a single crop (group of crops) is limited by the area under a single crop (group of crops)

$$
S_{j} \min \leq \sum_{i=1}^{m} X_{i} \leq S_{j} \max
$$


where $X_{\mathrm{i}}$ is the area of the $\mathrm{i}$-crop of the $\mathrm{j}$-crop group;

$S_{j}-$ area under the j-crop group:

$\mathrm{m}$ - number of crops in the group

Restrictions on the amount of area occupied by a single crop (group of crops) were established taking into account the recommendations on the optimal ratio of crops in crop rotations of different soil and climatic zones of Ukraine (On Approval of Standards..., 2010).

Thus, based on the recommendations, it was determined that the optimal area of grain crops in the Ukrainian steppe zone should be $50-80 \%$, and the technical $-25-40 \%$, the area under the winter cereals should not exceed $40 \%$ of the crop rotations. In general, mentioned Methodological Recommendations on the optimal balance of agricultural crops in the different soil and climatic zones of Ukraine have a wide range of agricultural crops and their place in the structure of landscapes. However, according to the author of this study, in these recommendations overlooked medicinal and aromatic and spicy crops, extremely promising for the Steppe zone under conditions of changing climate. The application of the developed model to farms makes it possible to optimize the structure of crops according to available resources.

Fig. 2 shows the actual structure of sown areas in the studied farms of the Steppe zone, characterized by the predominance of sunflower and wheat, and in many respects differs from the optimal one. Undoubtedly, the presence of 36\% sunflower and 29,5\% winter wheat in the structure of crops is completely inconsistent with the principles of sustainable development, regenerative farming and niche diversification. Although the diversification of production has a certain manifestation in the structure of crops are less common crops in Ukraine - millet, sorghum, oats, barley, buckwheat.

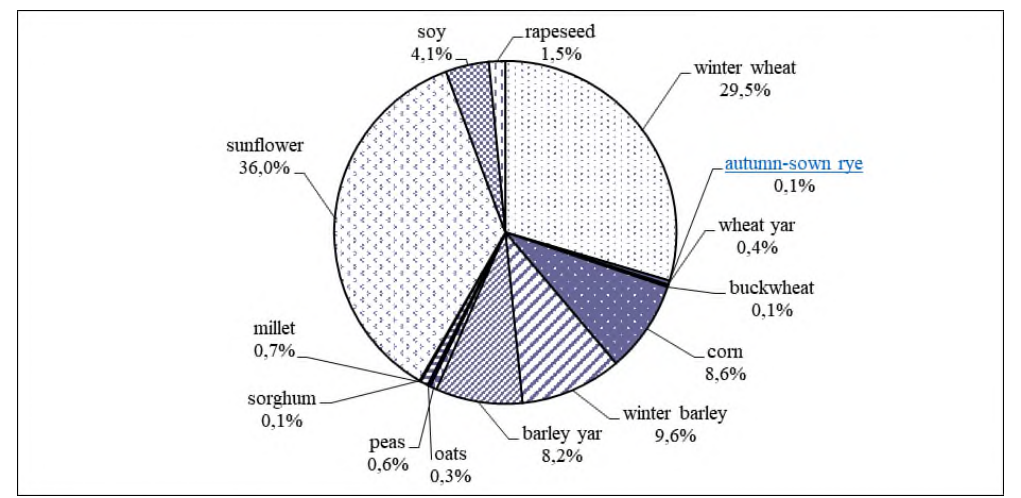

Fig. 2. Actual structure of the planted areas of the surveyed farms (developed by the authors).

It is worth mentioning that the actual structure of the sown areas of the farms under study in Fig. 2 shows directly available medicinal plants - but not because they are not grown by farms of the Ukrainian steppe zone, but because their specific weight is extremely scarce.

In turn, fig. 3 shows the optimal sowing area structure simulated by the author of the study for the farms, which were the object of the study. The calculated optimal sowing area structure contains the same crops that are present in the actual sowing structure, but provides for a reduction in the sowing areas of sunflower and winter wheat and an increase in the areas under soya, rapeseed, corn and niche crops. 


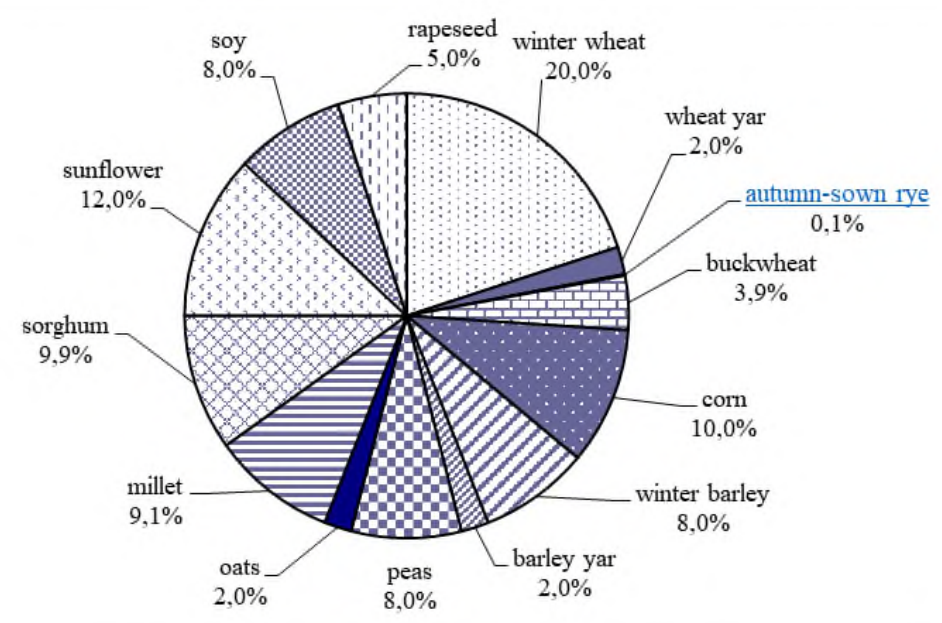

Fig. 3. Optimal structure of planted areas of surveyed farms (developed by the authors).

The analysis of the obtained result shows that observing scientifically grounded crop rotations the farms of the Ukrainian steppe zone with the area of agricultural lands of $50 \mathrm{~h}$ can get the maximum profit of 6470 thousand USD (Table 3) with the actual profit of 6760 thousand USD. In other words, growing the crops presented in table 1, the researched enterprises can make USD 290 thousand less profit. We assume that it is possible decrease in profitability in the first years of implementation of the achievements of science-based crop rotations is a barrier to their use by Ukrainian farmers, who do not think in the long term.

Table 3. Optimal structure of the surveyed farms in the Ukrainian Steppe zone

\begin{tabular}{|l|c|c|r|r|}
\hline \multicolumn{1}{|c|}{ crop } & square, $\mathrm{h}$ & $\%$ & $\begin{array}{c}\text { total spending, } \\
\text { USD }\end{array}$ & $\begin{array}{c}\text { income, } \\
\text { USD }\end{array}$ \\
\hline winter wheat & 11148 & 20.0 & 4764 & 1060 \\
\hline wheat yar & 1115 & 2.0 & 426 & 76 \\
\hline autumn-sown rye & 56 & 0.1 & 48 & 4 \\
\hline buckwheat & 2190.3 & 3.9 & 3000 & 207 \\
\hline corn & 5574.0 & 10.0 & 1750 & 834 \\
\hline winter barley & 4459.2 & 8.0 & 383 & 372 \\
\hline barley yar & 1114.8 & 2.0 & 1621 & 64 \\
\hline peas & 4459.2 & 8.0 & 219 & 246 \\
\hline oats & 1114.8 & 2.0 & 1493 & 16 \\
\hline millet & 5055.9 & 9.1 & 2312 & 544 \\
\hline sorghum & 5518.3 & 9.9 & 3139 & 1009 \\
\hline sunflower & 6688.8 & 12.0 & 2172 & 1095 \\
\hline soy & 4459.2 & 8.0 & 1717 & 424 \\
\hline rapeseed & 2787.0 & 5.0 & 23495 & 520 \\
\hline total & 55740 & 100 & & 6470 \\
\hline
\end{tabular}

Although a more detailed analysis of the optimization of the cropping pattern of the studied farms in the Steppe zone in Ukraine revealed the following. Such resources as fuel and lubricants costs and depreciation in enterprises are scarce resources. In the framework of the developed model they are exhausted in the process of cultivation of crops, which were included in the optimal structure of crop rotations. It is the «shadow price» in the non- 
linear model that is the Lagrange multiplier indicating the value of these resources compared to others. The value of this indicator shows how the value of the target function (profit) will change when the given resource types change by 1 dollar.

At the same time, we record the fact of underutilization of expenditures on mineral fertilizers, payment for services of third parties, other costs (including the cost of herbicides, means of protection) - through the reduction of areas under sunflowers, the cultivation of which in industrial scale just requires a decent cost in significant amounts. Therefore, the resulting savings in resources amounted to 1287 thousand dollars, or 5,2\% of actually used. The calculated sowing area in this case, as shown by the results of the study, corresponds to the actual $-55740 \mathrm{~h}$. It is reasonable to use the surplus resources to improve economic efficiency of production and optimal ratio of resource potential - in particular, to redistribute the balances in favor of scarce resources or partially on the sowing of medicinal plants.

Numerous scientists note that the introduction of medicinal grasses into the crop significantly reduces the negative pressure on soils of mineral additives and chemical plant protection agents, this will ultimately increase the environmental safety of the farmland and the resulting crop production. In addition, the use of chemicals to combat borers and pests, growth promoters and mineral additives is significantly reduced in the cultivation of these crops in the polish soil, the research has shown that these toxic substances can reduce contamination of soils in comparison with the cultivation of winter rye, sunflower, wheat and other major agricultural crops. It has been scientifically proved that to improve the biologicalisation of land cultivation it is advisable to use medicinal plants as a precursor for the main agricultural crops (Razanov S.F., Noveyshcha A.M., 2017).

Accordingly, on the second stage of modelling the optimal structure of planted areas of the studied farms with the inclusion of medicinal crops (Table. 4).

Table 4. Optimal structure of planted areas of surveyed farms in the Step zone with the introduction of medicinal plants

\begin{tabular}{|c|c|c|c|c|c|}
\hline crop & Square, $\mathrm{h}$ & $\%$ & crop & Square, $\mathrm{h}$ & $\%$ \\
\hline Winter wheat & 11148 & 20.0 & Medicine herbals & 1434 & 3.0 \\
\hline Wheat yar & 1115 & 2.0 & chamomile & 334 & 0.6 \\
\hline $\begin{array}{l}\text { Autumn- } \\
\text { sown rye }\end{array}$ & 56 & 0.1 & medicinal plants & 41 & 0.1 \\
\hline Buckwheat & 1672 & 3.0 & plum rose & 251 & 0.5 \\
\hline Corn & 5574 & 10.0 & thyme & 56 & 0.1 \\
\hline $\begin{array}{l}\text { Winter } \\
\text { barley }\end{array}$ & 4084 & 7.3 & butterwort & 56 & 0.1 \\
\hline Barley yar & 1115 & 2.0 & sage medicinal & 334 & 0.6 \\
\hline Peas & 4459 & 8.0 & nettle & 84 & 0.2 \\
\hline Oats & 1115 & 2.0 & $\begin{array}{l}\text { melissa } \\
\text { medicinal }\end{array}$ & 279 & 0.5 \\
\hline millet & 5574 & 10.0 & & & \\
\hline Sorghum & 4459 & 8.0 & & & \\
\hline sunflower & 6689 & 12.0 & & & \\
\hline soy & 4459 & 8.0 & & & \\
\hline rapeseed & 2787 & 5.0 & & & \\
\hline \multicolumn{6}{|c|}{ Total square, h $55740-100 \%$} \\
\hline
\end{tabular}

The model includes additional limitations on the share of medicinal crops in the planted area, such as X15, X16... X22 - area of medicinal crops, ha; p15 - p22 - value of profit per 1 ha of area under the relevant medicinal crops. 
Thus, we suggest that the structure of planted acreage of farms in the Ukrainian Step zone with up to 50 ha of land, the share of medicinal plants was 3\%. We believe that this share of medicinal plants in the overall structure would be appropriate for the first stage of implementation, given the low current limitations: lack of farmer's knowledge of medicinal crop production technologies, possible hesitation to introduce new risky crops into production, lack of quality plant material and capacity for drying medicinal plant crops, etc.

At the same time, just 3\% of medicinal crops in the structure of planted areas of farms in the Step zone with the area of agricultural land up to $50 \mathrm{~h}$, in our view, is the minimum threshold, which will contribute to the development of diversification in the surveyed enterprises, renovation of the quality of soil according to the principles of regenerative farming. In addition, growers of medicinal plants believe that it is enough to dedicate for cultural medicinal plants 10 hectares and you can already have a stable income. Practice shows that on such an area is easy to grow up to 10 tons of products, dried and sold only as a dry crop without processing - you need only to arrange an agreement with the manufacturer-wholesaler.

The choice of such cultures as chamomile medicinal, medicinal plants, plum rose, common thyme, common butterwort, sage medicinal, nettle and melissa medicinal is primarily determined by the fact that:

- the production technology of these medicinal plants is relatively simple;

- there is a possibility of harvesting several crops in a season and store dried medicinal plants $1.5-3$ years;

- may have the potential to scale up production;

- Most of these plants are drought-resistant and can grow in harsh conditions; thus, their production is adapted to the climatic conditions of the Ukraine's peninsula;

- are able to maintain the content of living resources in the soil, improving its structure, are good for the wheat, do not deprive the soil as the sleepyhead;

- are economically viable, export-oriented crops, such that they can be used in several directions.

In the process of modelling the optimal structure of planted areas with the introduction of medicinal crops to the studied farms of the Ukrainian Step zone, the structure of planted areas of medicinal plants themselves was also determined (Fig. 4), in which the greatest value is given to sage medicinal $(0.6 \%)$, Chamomile medicinal $(0.6 \%)$, Melissa medicinal $(0.5 \%)$ plum rose $(0.5 \%)$. 


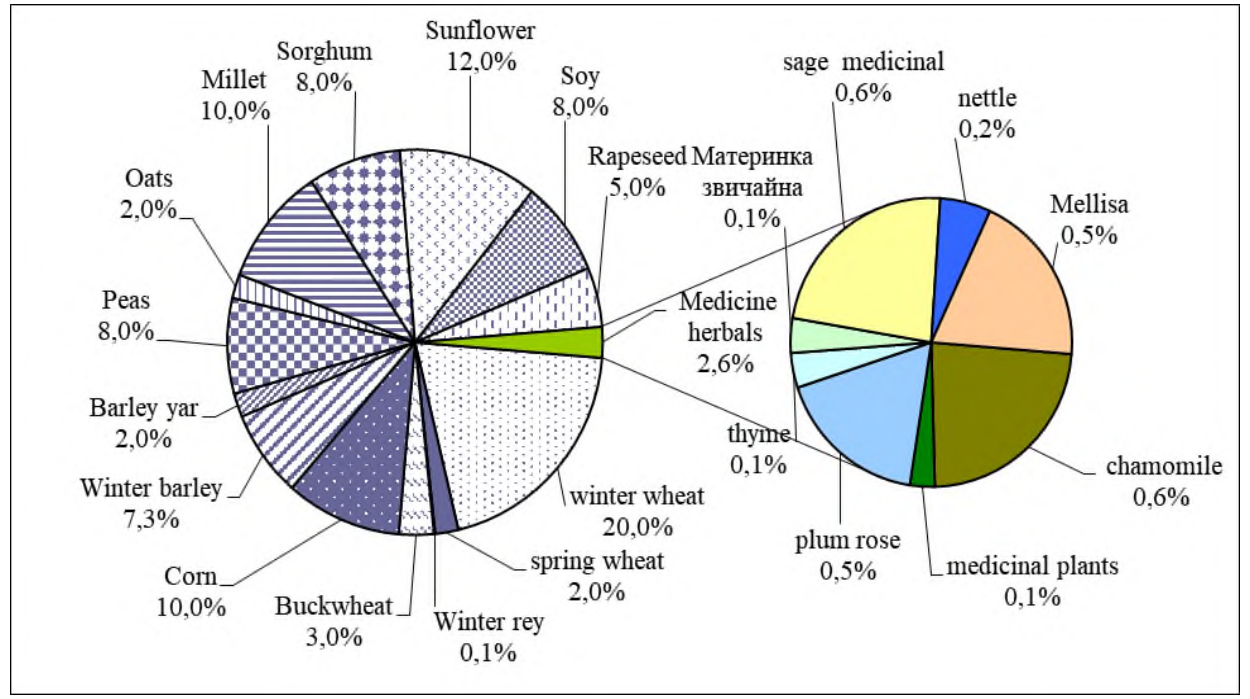

Fig. 4. Optimal structure of planted areas of surveyed farms in the Step zone with the introduction of medicinal plants.

\section{Conclusion}

Analysis of the result shows that if farms comply with the principles of introduction of medicinal plants in their crops they can earn a maximum profit totaling 7836 thousand dollars for the actual profit 6760 thousand dollars and optimal without the medicinal plants 6470 thousand dollars. This actual costs will grow to 26973 thousand USD, which is 2190 thousand USD more than actual costs and 3477 thousand USD more than the optimal structure without pharmaceutical plants.

Taken into account the fact that in the second and subsequent years the yield of some medicinal plants is considerably higher than in the first year (e.g. in the second year the mutton was "rejuvenated" by cutting the paddocks, after which the productivity and bushiness of the plant increases), Costs decrease, resulting in a total cost of USD 26109 thousand (USD 1326 thousand more actual costs, USD 2612 thousand more for the optimal structure without medicinal plants and USD 864 thousand more than in the first year of cultivation of medicinal plants [14-18].

Total turnover in the second year of the implementation of optimal structure of planting areas surveyed farms zone Step introduction of medicinal plants could reach 11357 thousand USD million, 4597 thousand USD more than the actual level and 3519 USD more than the first year of cultivation of medicinal plants. The cost-effectiveness of the enterprises increased from $27.3 \%$ at the actual planting rate to $43.5 \%$.

Thus, the simulated optimal structure of planted areas with the introduction of medicinal crops to them produces low effects for the producers - the growth of profitability, cost recovery is achieved, as evidenced by the rising profitability level. The fact that the introduction of medicinal plants in the structure of planting producers will not receive profits from the first year, it also indicates that the development of pharmaceutical plants requires grounded long time strategy. In view of the role of Ukrainian agribusiness in the world in general and in Europe in particular, and in view of the significant demand for medicinal plant products in today's world, the presented material is of practical value. Its use in practice will contribute to the development of both Ukrainian and world market of medicinal plants. 


\section{References}

1. P. I. Boiko, Principles for the development of rationing systems in Ukraine, P. I. Boiko, D. V. Litvinov, J. S. Tsimbal, S. O. Kudria, Proceedings of the National Research Centre «Institute of Earth Sciences of the National Academy of Sciences», 1, 3-14 (2018) http://nbuv.gov.ua/UJRN/znpzeml_2018_1_3 (Last accessed 11.01.2021)

2. T. Galushkina, Economic instruments of environmental management (theory and practice): a monograph. Odessa: IPRAAE UNAS, 280 (2000)

3. Gastronomic trends 2020 (2020) https://aquafarm.com.ua/aquafarm-blog/ryba/trendy2020-roku/ (Last accessed 11.01.2021)

4. N. A. Gerasemchuk, Economic and Financial Risks: workbook : guide (revision), N. A. Gerasemchuk, T. V. Mirzoieva, O. A. Tomashevska, 407 (Kyiv : CP. Comprint, 2020)

5. V. Kaminskiy, Organic farming is the way to food security. Viche, 9, (2014) http://veche.kiev.ua/journal/4161/ (Last accessed 14.01.2021)

6. L. S. Kvasnitska, Productivity of short-term crop rotations in the right bank foreststeppe

file://C:/Documents\%20and\%20Settings/User/\%D0\%9C\%D0\%BE\%D0\%B8\%20\%D 0\%B4\%D0\%BE\%D0\%BA\%D1\%83\%D0\%BC\%D0\%B5\%D0\%BD $\%$ D $1 \% 82 \% \mathrm{D} 1 \% 8$ B/Downloads/znpzeml_2015_1_4.pdf (Last accessed 21.01.2021)

7. N. Kuzio, 7 non-trivial agrarian trends of the new decade (2020) https://www.growhow.in.ua/7-nebanal-nykh-ahrarnykh-trendiv-novoho-desiatylittia (Last accessed 21.01.2021)

8. H. Jafari, M. A. Ahmadian, A. Tarhani, Production of Medicinal Herbs, an Approach to Sustain the Rural Economy (Case Study: Villages in Ghochan County). Journal of $\begin{array}{llll}\text { Research and Rural Planning, 6(1), 173-187 } & \text { (2017) }\end{array}$ https://doi.org/10.22067/jrrp.v6i1.56119

9. D. Lange, Medicinal and aromatic plants: trade, production, and management of botanical resources. ActaHortic, 629, 177-197 (2004) DOI: 10.17660/ActaHortic629.25 https://doi.org/10.17660/ActaHortic.2004.629.25

10. V. Mincharenko, Medicinal plants of Ukraine. Encyclopedia of Modern Ukraine. Betaversion (2016) http://esu.com.ua/search_articles.php?id=55467 (Last accessed 25.01.2021)

11. T. Mirzoieva, Trends in the situation of medicinal plants in Ukraine and the world. Collection of scientific works of NUK, 4, 32-37 (2019)

12. T. Mirzoieva, O. Tomashevska, Economic assessment of concentration and monopolization of the market of spices and essential oil plants in Ukraine. Modern Management Review $27 \quad(1 / 2020)$, DOI: $10.7862 /$ rz.2020.mmr.7 http://doi.prz.edu.pl/pl/publ/zim/415

13. Official site of the State Statistics Service of Ukraine (2019) http://www.ukrstat.gov.ua (Last accessed 26.01.2021)

14. Optimization of planted areas of sunflower. Agronom magazine (2013) https://www.agronom.com.ua/optymizatsiya-posivnyh-ploshh-sonyashnyku/ (Last accessed 26.01.2021)

15. Approval of the norms of the optimal mix of crops in different natural-agricultural areas: Decree of the Cabinet of Ministers of Ukraine of 11.02.2010 № 164. https://zakon.rada.gov.ua/laws/show/164-2010-\%D0\%BF\#Text (Last accessed 26.01.2021) 
16. C. F. Razanov, A. M. Nastoiascha, Effectiveness of cultivation and use of medicinal plants in modern ecological conditions of the docklands. Agriculture and forestry, $6(2)$, 141-149 (2017)

17. Z. Z. Sobko, N. M. Voznuk, Influence of agrometeorological factors on the yields of thermophilic crops (in the case of the Rivne region). Molodiy vcheniy, 8, 5-9 (2017)

18. A. O. Sokolova, L. F. Petrikanin, L. V. Sichuk and etc., Strategic priorities for socioeconomic development of rural areas of the Volyn region in the context of European integration : a collaborative monograph, 152 (Lutsk, Nadstiria, 2018) 